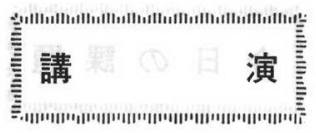

\section{美しきあかりの心 一美しく住まうために一}

\author{
終身会員 東 宮
}

「あかりの日」に，照明学会北海道支部主催ならびに諸 団体後援の講演会に招聘を賜り，たくさんの道民のかたが たに「美しきあかりの心」，「美しく住まうために」のテー マで括できますことは，たいへん光栄に存ずる次第で す.

本日は，抽象的な「美しいあかりの心」，「美しく住まう ために」というテーマではありますが， あかりの記念日 に，あかりに興味を持っていただきますならば，私の役目 も果たせるのではないかと考光ます。

皆様にあかりの魅力の魔法をかけることがでさましょら か. 講演が終わるころまでにそれが果たせますことを希望 しながら，与兄られました時間を皆様と過ごさせていただ きたいと考えます。

なぜ「美しいあかりの心」というテーマにしましたか は, これからはコンピュータにインプットしますと，どの ような設計でもでき上がって来る時代でして，ハード， ソ フトの展開はたいいんきめ細かい，特に照明技術の点につ いては，日本のレベルも世界に伍しまして，GNPはただ今 2 位で，照明の業界もオリンピックのマラソンでい壳ば， 第 1 集団の 1 位， 2 位， 3 位で走っているような状況です.

しかしながら，まだまだ実際に皆様の家庭の照明という 問題になりますと，技術はたいへん進んでいるのですが， それを実際に利用して，住まいでどのようなあかりで生活 されているかということになりますと，失礼ですがまだま だ蛍光灯のサークルランプが 1 本, 2 本はいっている器具 をつけまして,引っ張るごとに上のほこりが落ちてくる, と いらようなホームライトの生活ではないでしょうか(笑),

「紺屋の白袴」で，私の家などもそのようなところがあ りまして，これから一層あかりにロマンを感じ，美しいと か，きれいだといらことを乗り超えて，本当に一味違った 心のこもったあかりを考党ていただく、ハードとソフトだ けでなく，ヒューマンウェアの人に対します技術と申しま

† Heart of Beautiful Light-for Beautiful Human Life
* 侏東宮照明設計事務所

この講演は, 昭和60年10月21日, 札幌 STV ホールにおいて開催さ れた「あかりの日記念講演会」(主催 : 照明学会 北海道支部) で講 演されたものである。

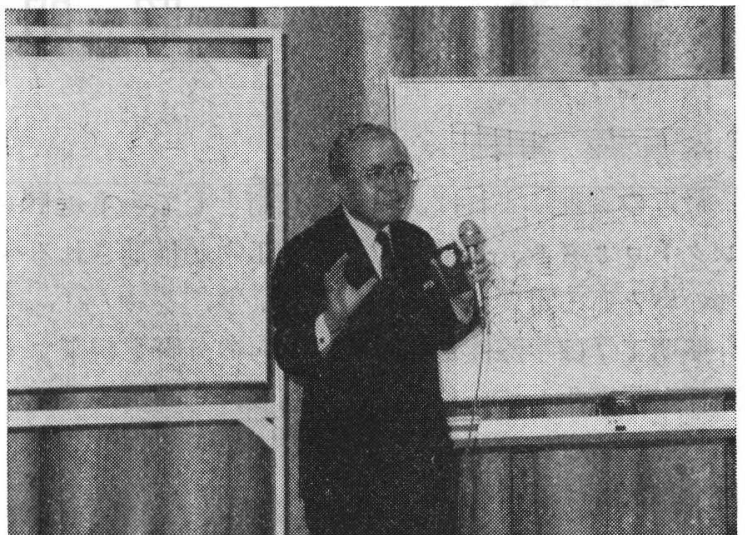

すか, ヒューマンな心で原点に返って，「美しいあかりの 心」とはどういらものなのか, いっしょにあかりの記念日 にふさわしく㭶光いただけたらと思います。

さて，このホールの私の演壇の部分はスポットライトが 当たって扣り（照度計ではかる），2,000 lxぐらいになっ ております。ささきぼ皆様方の席のところの照明を測りま したところ，全体的に $50 \mathrm{~lx}$ ぐらいでした.

家庭の照明の中で，食事をするときの明るさは，経済性 も含めまして 200 から $5001 \mathrm{x}$ ぐらい. $3001 \mathrm{~lx}$ ぐらいの明る さがあれば，掠いしく食事をすることができます。抺子さ ん達が勉強するときの明るさは，どのくらいの明るさがよ ろしいかというと，幅が広いんですけれども，300から 1,000 1x. 大体 500 1x ぐらいあればよいとしています。奥 様方が料理を調理するときの明るさも，200から $5001 \mathrm{x}$ が 適当です。

そのようなわけで，照明の明るさの感じをちょっとつか んでいただこうと思い照度の話をしたわけです。

さて，美しく住まうにはどらいうことがたいせつなのだ ろらか. 特にこの美しいといらのは，きれいとか美しいと いうことを乗り超えた，一つの美学といらか，原点の問題 で，今までよりも一味違った住まいを求めていくには，ど らいらことがたいせつなのかということです。

家には家族が和りますが，家の内に扣られる“家内”奥 さんが美しいといらことがたいせかです．住まいの中で奥 さんが美しい一女性が美しい一といらことは，男性がやさ しいということだと思います。男性は夫を含め，男の子供 達が母や姉妹に対して一女性に対して一やさしい家庭は必 ず温かい豊かな家庭だと私は思います。そういらわけで, 美しく住まらためには，立派な家を建てて住まうこともた いせつですけれども，外から見てもその家族が幸福に，豊 かに，明るい生活をしている住まいこそ，本当の美しい住 まいであると思います。そのよらな，なごやかな家庭が生 まれる美しい住末いはどのようにして生まれるか。

中国の老子は，「室の室たるは空なり」といって和りま す.これをインテリア，住まいに考えて見ますと，部屋の 
部屋たるは，スペースという残された空間がたいせつなの です。．家具，調度品をいっぱい，たとえば 4 畳半にそれこ そベッド，テーブル，椅子など，狭いスペースに家具をた くさん並べる，それがインテリアのデザインではありませ ん．家具を配直したならば，その残された空間がどのよう にうまく使われるか。そのらまく残された空間に人間が住 むわけですから，その住先空間のキャパシティ（容量）が 美しく住まうために非常にたいせつな条件です.

さて，幸せな家庭をつくり上げていく空間のキャパシテ ィのうちでたいせつなのは，その空気の環境です，電気の エネルギーを変換した「光と熱と音」を，この空間にじょ らずに有効に使うことで，美しい住まいを求めることがで きるのではないかと考皇ます。その美しいあかりを求める にあたって，ぞのようなあかりがたいせつなあかりなの か. 日本という国の日本の美しさ，諸外国に比べて何が日 本の美しさなのか，といらことを考光て見る必要があり亦 †.

日本の美しさをつくり上げているものは太陽であり，四 季の美しさである，ということです，四季の変化が日本の 美しさをつくり上げている.

私達，人間はその自然の中に住んでいるわけです.

この春夏秋冬の変化が，日本の自然の美しさをつくり上 げている，この日本の美しさをつくっている自然の変化 が，注かの国々と多少違っているのは，汪３か月ごとに すばらしい春, 夏, 秋, 冬の四季の変化によって, 日本の 美しさが生まれるわけです。

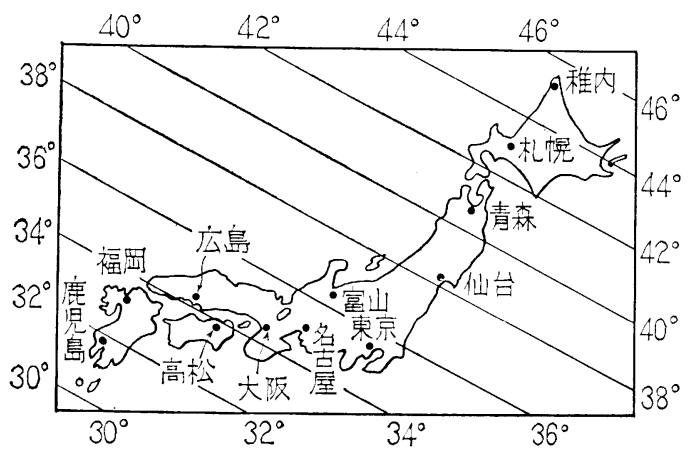

図1日本の緯度困

なぜ，十本の国に 3 か月ごとに 4 シーズンあるかといら のは（黑板に地図を描く），注添，稚内が北緯 46 度で，沛 縄が26度であり，札晥は汪淁43度です。このように日本列 島は汪添26度から46度に位します（図 1 参照）太太陽の光 と熱が常に地球にそとが叔て沶り, 地球は太陽の周りを回 っている. 春秋の太陽にいちばん近いところは赤道です。 夏は北半球が, 23 度30分, 太陽の側に倾斜して回転し, 南 に移動して日本の国は赤道に近ついて回転してきて, 札幌 の43度より23度30分引くと, 約北緯 20 度, ちょうど札㹸が 台湾ぐらいまで回って来ます。このように，札幌の夏は南 の台湾のように暑いのです (図 2 参照). 冬になると, 今 度は太陽側から遠くなり, 秋の軸から23度30分傾斜して回 転しますから, 日本列島は回転しながら北に移動して行

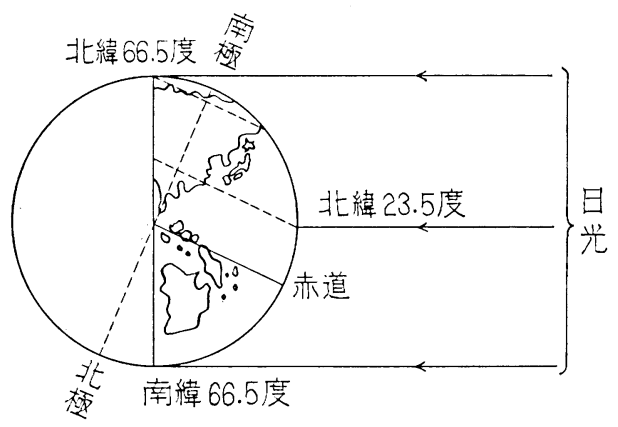

図 2 北半球の夏至 $(6 / 21)$

き，札幌の43度に23度を足しますと約66度，ノルウェーの オスロとか，フィンランドのヘルシンキより北の緯度にな り，札幌の冬はたいへん寒くなり，札幌で冬季オリンピッ クができるほどの雪もたくさん降るわけです。

このよらなわ忛で，23度30分傾斜しあって夏至と冬至が あること，そして春と秋は，太陽と90度の軸を中心として 太陽の周りを回っている，そして北緯26から46度の緯度の 中に日本列島が位しているというところに，日本の四季の 美しさを太陽の運行がつくり，自然の恵みをつくっている わけです。

不思議なことに，世界の GNP 1，2 位を占めているの はアメリカと日本ですけれども，アメリカも20度から50度 近い緯度の中にあります。東京は35度ですが，ワシントン のポトマック河畔は38度です. 日本の桜がー（尾崎さんが プレビントした桜）ーアメリカの広く空気のよいところ で，日本の桜よりも美しく咲いているというのは，同緯度 で太陽の恵又を受けて，四季の変化が似ているからです。

今世界を経済的に引っ張っているのが，20度から50度の緯 度の中にある民族であるというのも，何か不思議なご縁て はないか.これは太陽が四季の変化に対応する民族をつく ってきた，日本人は非常に勤勉な国民であるとか，変化に 対応しやすい，気が短いなどなど，いりも3か月拈きに4 シーズンが毎年, 繰り返し, 繰り返えされる太陽と地球と の運行のバランスの中に日本民族をつくり，日本の美しさ をつくって来たのだというように感じます。

北陸に講演旅行した折，740 年前，道元禅師が開祖した 福井の永平寺を訪衫る。道元禅師が「春恃花，夏汪ととぎ す，秋は月，冬雪冴えて涼しかりけり」と，雪，月，花と 詠んでいる，日本の美はこの四季の変化にある゙としてい る。道元禅師が24歳のときに中国へ渡り，6年修業し，㷌 国，そして改めて日本の美しさを詠んでいる。

私も毎年 1 回か 2 回，外国へ旅行する機会があります が，皆さんも 6 月とか10月とか，非常によい時期に外国へ 旅行します。的北欧の冬法朝なかなか太陽が出て来な い. 午前11時ごろ太陽が出て, そしてもら午後 2 時から 3 時ごろには太陽が沈んでしまう。そういう国もあるわけ で，特に北極，南極にいたっては，北極は冬たいへん寒 く，太陽も全然出て来ない。それに反して南極は白夜の太 陽は一日中沈まない。 
しかし，日本列島は 3 か月ごとに四季の変化が美しく， その恵みを受けこの恩恵の中に日本が㕕くまれて来てい る.このような四季のロマンが日本の美しさをつくって来 ているのだと思います。

さて，この太陽の光の恵艾に対して，私達日本の住まい がぞのようにこの美しい自を取り入れて米ているかと いうことを考劣て見たいと思う。

京都の南禅寺や竜安寺の庭園を見ると（黑板に絵夌描 く), 庭には白玉砂利が兓いてあります。この玉仯利に対 して太陽の光, 月の光があたり, これが反射して室内には いって来る反射効果を, この玉砂利が持っている（図 3 参 照). 太陽の光を一次光源としますと, 玉砂利が二次光源 になり，そして明り障子を通して透過した光が柔らかい光 となってこの方丈の間にはいって来るわけです。室内には いって来た光を白壁や金襖が受光面となって間接光とな る.
珠光と紹鷗は北侧に庭をつくっており,なぜ北側に庭を つくったかというと，たいへん意味があるわけです。太陽 の光が当たりますと, 花々は南に向いて咲くわけで, 部屋 から見ます情景は，いちばん美しい自然を見ることがで き，観賞与ることができる、亦た露路を通っで践口に向か うときでも，いちばん良い条件につくられたわけです。千 利休は，これを是敢比東南の方向に設けて積極的に太陽の 光を採り入れることを考えたわ忛です。

特に, 利休の代表作として「待庵」という2帖の茶室が ある(黒板に絵を描く) (図 4 参照).

茶室は 2 帖の $1.8 \mathrm{~m} \times 1.8 \mathrm{~m}$ のほぼ立方体の窒内空間 で，床の間があり，天井は 3 種の意匠で作られている。壁 には二つの連子空，躍口の上に格子空があり，それぞれ採 光の効果を持っています.

このような 2 帖の小さな茶室空間を考え，なおなな゙こ

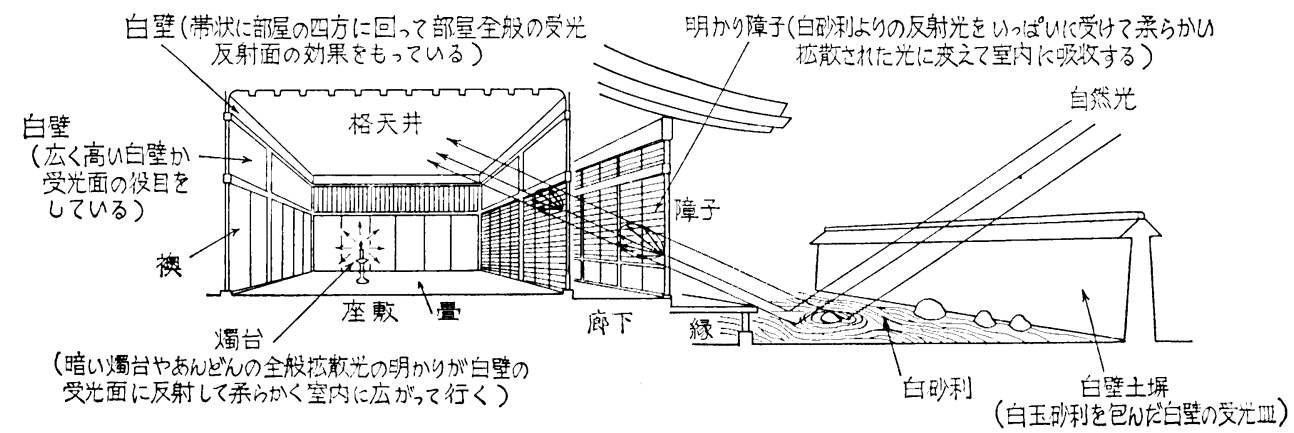

图 3 南禅寺方丈庭園採光技法分析图
谷崎潤一郎著に「陰掔礼讃」があり柰が，陰掔のイン エイのエイは毉（かげる）という字で, 光がだんだんと䍓 ってくる．扣日さまがだんだんと第ってくるというのが， 日本の陰鷖のロマンであるといらこともいえるわけです. このように，婜ってきた光を白壁や金襀が受けて立つ面が 日本の建築には考えられています。

このように，日本の建築は四季を通して，長いひさしに 対して側面から光を導入ナる. 日本の建筑は, 屋根と柱の 構造によってできており，空父の流れ，光の流れは侧面か らはいって来る仕組又になっています。外国の建物は, 不 を積み上げて造り，一つ一つ分化した部屋をつくってい る. 日本の空間恃未分化の空間です，襖を建てると二つに 分かれますが，それを取りはずしますと広く使光る。欄間 を設けて次の部屋に光を採り入れるようなロマンがある。

また，日本建築の採光の方法としては，明り障子の效果 が代表的なものである．燭台を立てたり，あるいはあんど んを立てたりして, 局部的なあかりをともし, 全般的な光 は，この障子越しの光を通して壁上面の白壁に当て，それ を柔らかく反射させて, 部屋全体に戻してくるといら光の 作法も日本の採光の一つのロマンです.

寝殿造りから書院, 書院から数寄屋, それから茶室建築 と, 日本の建築の流れのうちで, 現代建築の原点といらと 茶室であるといえる。
のよらな小さな躍口を設けたのか，䠰口は背を低くして入 室したり，武士に刀をとらせるとかの茶の精神の現われと いうことも事実あったのでしょうが，私は最近，茶室を訪 ねて感じますのは，天井の高さはほぼ $1.87 \mathrm{~m}$ と低く，茶室 に拈客が立ったままはいって来ると，人間の目の高さが $1.5 \mathrm{~m}$ 前後として, 実に小さな天井の低い部屋として感じ ます。ですから躍口から背をかがめて入室する際, 畳に手

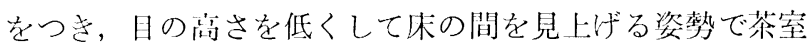
内部を見せる. 2 帖の部屋を茶の道具として, 器として鑑 賞させる。そういう利休の茶道の作法があったのではない か。ですから，躍口ょり入るとさには，さっとはいらずに 日を上げて，ぜひ茶室を鑑賞していただきたい。とこで初 めて，2帖の部屋で辟さが $1.8 \mathrm{~m}$ の茶室空间に「茶室の 心」を見ることがでさます。

またこれら速子空と格子空から差し込んでくる明りの 效果によって，この 2 帖の部屋が浮き上がって見光，躏口 の戸を開けたとき，背後から光が昭に反射して床の間に， 壁面に天井面に当たる．完全に計算し尽くされた状態で光 がこの 2 帖の小間の中に展開している.

特にすばらしいの法，室の4隅のうち，炉のある角の壁 面沙喰で円弧に造形され，じょうずに集光させ，末た反 射させ，炉周辺を明るくする効果を利休㛈古ついてい る.この 2 帖の茶室は, たいへん美しいあかりの心を持っ 
た日本の住まいの原点であるといわざるを得ません，その 魅力というのもやはり速子空や，格子空を通しての明りの 障子にあるとい党すす。

現在は, 蛍光灯とか, 電球, 水銀灯, メタルハライド, 高压ナトリウムランプなど，たくさんの光源が製造されて いますが，「美しい住まいのあかりの心」の中で，明かり 障子をもら一度見直したい. 日本の四季の光を通して生来 れる明かり障子の魅力を再認識願いたい。

なぜ障子にロマンがあるかというと，障子は外からの光 透過する透過材だけでなく，反射材としてもまたたいせ つな室内の仕上げ材でもある.

日本の障子の透過率は，薄く，白く与かれた美濃紙で大 体30から50\%ぐらいです。障子は夜になると室内の明かり に対して，壁面と同じように反射材となる。そして，その

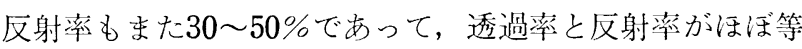
しいところに，光に対与る障子の魔力があると思う。障子 は光を通すだけのものでなく，光を反射させる日本建築の たいせつな仕上げ材である。

また和室空間の仕上げ材として，天井材の檜とか，杉材 もほ添30から65\%ぐらい，壁の漆喰，襖なども大体30〜75 \%ぐらい，胃もほぼ40６0\%ぐらいで，各和室空間の仕上 げ材の反射率がほぼ等しいというところに，日本間の魅力 がかくされてい亚す（表 1 参照).

表 1 和室建築材料の反射率（建築学会資料抜萃）

\begin{tabular}{|c|c|c|}
\hline & 材 & 反射率 $(\%)$ \\
\hline 天弗材 & $\begin{array}{l}\text { 建築木部 } \\
\text { 檢 材 (新) } \\
\text { 杉 材 (" }) \\
\text { 杉赤目材 (" })\end{array}$ & $\begin{array}{l}55 \sim 65 \\
30 \sim 50 \\
25 \sim 35\end{array}$ \\
\hline 壁 & 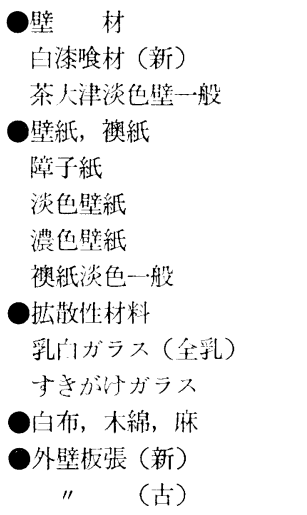 & $\begin{array}{l}75 \sim 85 \\
40 \sim 60 \\
30 \sim 50 \\
40 \sim 70 \\
20 \sim 40 \\
40 \sim 70 \\
60 \sim 70 \\
30 \sim 40 \\
40 \sim 70 \\
40 \sim 55 \\
10 \sim 30\end{array}$ \\
\hline 床 & 星: (新) & $40 \sim 60$ \\
\hline 地表面 & 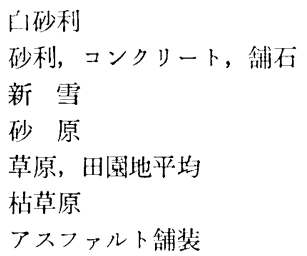 & $\begin{array}{r}20 \sim 40 \\
15 \sim 30 \\
80 \sim 98 \\
10 \sim 20 \\
5 \sim 15 \\
10 \sim 30 \\
15 \sim 20\end{array}$ \\
\hline
\end{tabular}

明るさというのは, その部屋の材料の反射率と, その面 の明るさ (照度)を掛けた数字,「光束発散度」といいま して，この光束発散度は「照度 $\times$ 材料の反射率」で表わし
ます。障子越しに光がはいってきて，天井，壁あるいは床 に当たる，それぞれの材料の光の反射率がほぼ同じなの で，ひとしく光が当たり泉らかいあかりの効果が，日本間 の空間を造り出している.

これから家を建てる力は，少なくとも一室は和室をつく って住まうことが，日本人として生活の原点に戻り，一つ の美しい住まいの姿を家庭に造り得るのではないかと考光 ます。これからの日本の住まい造りには洋間ばかりでな く，日本間の魅力を再発見願うことがたいせつなことだと 思います。

それでは，和室の照明器具はどのようなものが良いかと いうと，イサム・野口さんのちょうちん（提灯）に見られ るように，等しく光が出る全般拡散照明の器具がよい。下 方向にだけ光が出る直接照明器具を和室に使いますと，天 井や壁が暗くなってしまう。和紙で作られたちゃらちんの ような照明が，なぜ日本間に合うのか，またなぜ日本全国 津々浦々，絑光灯の和風ホームライトが各家庭で愛されて きたのか。それは，これまで説明したように，天井から 壁，林末で全体に柔らかく，等しく反射する空間に，全般 払散照明の器具が適していることを，日本人として自然の うちに理解して，全般的に光の出る照明を選んだことにあ ると考光られる。

従来，日本間では茶の間として，ちゃぶ台を設䏚，食事 をする。終わったらふとんを敷いて寝室にするというよう な多目的な末分化の多様化した空間の中で暮らしてきた。 ですから，ベットの寝室も良いのですが，土曜，日曜日に は和室にふとんを敷いて寝るとか，日本人としての生活の 原点に返ることも，これからの日本人として必要な住委い 方のロマンがあるのではないか。

このような，質的に原点をたどっていく中に，やはり日 本人として，美しく住まら基本があるのではないかと考え 来す。

寝室の照明一つにしても，よくある例で，洋間の誛室に 照明はというと，ただ天井にダウンライトを4個つける。 聂て見上げれば，ダゥンライトの光が本ぶしくて困る．ダ ウンライトだけが光っていて，天井も暗くなり，壁も脂 い。これからの寝空は，照明を含めた天井の材質，意匠に 心配りをすることがたいせつです。

これに反し，日本間は，非常にらなく，やさしく寝かせ てくれるよらな光束発散度の室内の仕上げ材になっている といらことを考充执したいものです。

このような，日本の住来いを原点的に考光，太陽の恵文 が与えてくれた日本の美しさの中に㕕くまれた，日本建築 の光の採り入れ方と，室内の仕上げのロマンを認識願い， もう一度，日本のすばらしさを考えなおしたい。そこに日 本の良さを再発見することがたいせつです。

次に美しく住まうためのあかりに市っても，明るさ，照 度だけでない建築に関わる光を考えたい。

建築に関わる光として，(1)見るための市かり，(2)思い， 考えさせるあかり，(3)感じさせるあかりの効果がある. 
日本の住まいのあかりは，見るため，見せるためのあか り，仕事を与るためのあかりに重点がおかれ，特に昭和48 年以降，石油ショックによる影響もあって，明るければ良 いとする照明になりがちであった。

しかし，これからは住まいの照明にあっても明るさもた いせつですが，一味違った零囲父を造り出すあかり，落ち 着いて何かを思い，考光させるあかりが求められます。

それは何かといらと，たと光ば，障子が造る空間もその 一つです，子供の勉強部屋でガラス戸だけでなく，内側に 障子戸を設け，勉強するとさにこの障子を閉めることによ って，この空問が透光不透視の世界，光ははいってくるけ れども，外は見えないといら透光不透視のたいへん落ち着 いた思考するにふさわしい架間となる，寝空，書斉など も，洋間であっても内側に障子戸を設けることを推薦した い.

また日本間の中央のあかりのほかに，間挍照明による休 の間のあかりが掛け軸に柔らかい光を与え，落ち着いた空 間を造り出与。このようなあかりが，思い，考光させる一 つのあかり効果なのです。

また，北海道の原野に沈九でいく夕日，地球を間接とし て，㕵觉あか敞色に輝き染める宇宙が描く間接照明，方丈 の間の大壁にあたった光，仏間のお釈迦さまにあたった間 接光などが，人間に何かを思い，考えさせる．読み，書 きそそろばんの照明だけでなく，このような，何かを思 い，考光させる閌接照朋の效果を，住まいの中のあかりと して見直したいものです。

さてもら一つたいせつなあかりの効果として，見るた め，思い，考えさせるあかりのほかに，感じさせるあかり の效果があります。たと社打灯明あかり，クリスマス やバースディケーキに立てるろうそくのあかりなど，ろう そくのきらきらゆらめく光が，網膜をここちよく刺激し， 何か神秘的な，華やいだ，管華なあかりとして感じさせる ものです。こらいら思想がシャンデリヤのあかりです。き らさらと輝く光が，星空のようなロマンを人間に感じさせ るのです.

これは特に，所有欲，食欲にも影等があります。食欲と か所存欲をかきたてる商它，特に飲料店関係などには必要 なあかり効果です、ツィンクルな魅力的な輝きのあるあか りが墑業施設にはたいせつなのです。

家庭でも，たと党ば食卓の上の，楽しいきらっとしたあ かりなど，食欲をそそり，食卓のディスプレイに楽しさや 豊かさの感じを与えてくれます。

このよらに，感じ，感動されるあかりが住まいの中にも 必要です。高価なシャンデリアを取り付けなさいというこ とでは尓くて，従来のただ照度，照度の時代から，何かを あかりから考光，思わせるような，そして心なごも感動を 与えるようなあかりを美しく住まうためにも，造っていた だくこともたいれんたいせつなのではないかと考えます。

さて，少し実際の例として考光てみますと，子供部屋の 照明にしても, 従来, 6 帖の 部屋に $20 \mathrm{~W} 2$ 灯用蛍光ラン
プ露出の逆富士形器具を付けているとして, これを直接, 光源が見えないように，乳白色のプラスチックカバーに入 れた器具に変えますと，柔らかい「グレアレス」(まぶし さを少なくする）光となって，落ち着いた勉強部屋のあか りになります。

そのときに $20 \mathrm{~W} 2$ 灯用でなく 4 灯用にしますと, 成績 も 2 から 4 になります.（笑）

2 灯用を 4 灯にすれば倍の電気代になるとすぐ計算しが ちですが, $20 \mathrm{~W}$ の蛍光灯は安定器の口スを入れて $25 \mathrm{~W}$

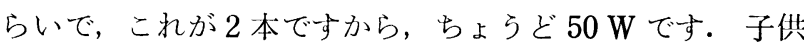
の勉強する時間を計算して，中学生で毎日午後 4 時から午 前 2 時まで 10 時間（笑）勉強したとして， $50 \mathrm{~W} \times 10$ 時間， $500 \mathrm{~W}$ 時，つまり，電気料金は $1 \mathrm{~kW}$ 時で約 30 円ですから， $500 \mathrm{~W}$ 時が15円. 2 灯ふやして 4 灯用にしても，1 日15円 のアップで斉みます，今，子供の扣やつ代と比較しても， 15円で明るく，子供の目を守り，落ち着いたあかりの環境 ができるわけです。次に奥さま方のために，扮料理をおい しく見せる照明のテクニックを括話します。

食事をするとき，テーブルの上の明るさは $300 \mathrm{~lx}$ 㹥ま しいです. $100 \mathrm{~W}$ の電球をテーブルの上, 大体 $75 \mathrm{~cm} く ゙ ら$ いの高さにつり下げれば，拈よそ $300 \mathrm{~lx}$ の明るさが得られ ます，食卓の照明器具は，天井に直に取り付けるより，つ り下げて食卓上で華やいだ感じにすることがよい。

また，食物をおいしく見せ，食べさせることがたいせつ で，食物の色は，赤燈黄緑系で，青紫系はほとんどありま せ九．特に赤系が多く，この色を美しく見せる光をたいせ つに考えれば，食物を打いしく見せることができます。

监光灯は一般的に黄と青が強調され，赤系は少なく，肉 や刺身などくすんだように見える，白熱電球は赤登黄緑の 順のスペクトルに，赤がいちばん多く，肉や刺身の赤が強 調され，新鮮に見光，点光源ですから陰やボリウム感，立 体感が出て, 光の色妇暖か味があり，料理が美しく見光， 蛍光灯よりエキーイティングな感じがします。

をたランプの数が，1灯より 2 〜 灯の汪うが輝やいて にざやかになり来与。食卓の照明は $100 \mathrm{~W}$ 一で明るさは 十分で電父代を計算しても，夕食時間，1時間としても $100 \mathrm{~W}$ 時ですから 3 円です. $60 \mathrm{~W} 3$ 灯使用しても $180 \mathrm{~W}$ 時 5 円40銭で，家族全員の夕食の照朋の筺気代がまかなる わケで, 住まいの照明用電力の効果性, 有効性ということ がご理解いただけると思います。このようにいたします と，ご主人が途中どこへも沈没せずに，早月に家へ抢帰り になり，食卓を围及，美しい市かりの下で，美しい住まい をェンジョイしていただけるものと思います。

最後に，美しく住まうための実践的各論支提案します.

（1）部屋はできるだけ間仕切らず，広く使うことがたい せつです。

（2）天井はできるだけ高く取ること，上天井，吹き抜け 空間を考えることも楽しい。

（3）洋室，寝室，子供室，書斉など障子を設计，障子の 魅力を再発見する. 
（4）寝室は，天井面を美しく，特に照明はソフトに，寝 て見て目に美しい器具を選ぶこと.

（5）採光や住まいの照明を一層たいせつに計画する。

以上, 美しいあかり, 美しく住まうために何らかのご参
考になれば幸いです。どらもご清聴ありがとうございまし た。

（受付1985年12月23日）

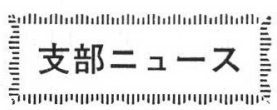

一関西支部一

照明学会関西支部見学会を実施して

照明学会関西支部主催の見学会が 9 月 20 日(金), 昭和59年度 照明普及賞に輝いた神戸ポートアイランドホール（ワールド記 念ホール）と，昭和59年10月に完成した関西電力株式会社総合 技術研究所, 山崎実験センターに40名が参加して行なわれた.

8 時 30 分，国鉄大阪駅西口に集合し，バスにて最初の見学 先, 神戸ポートアイランドホールに向かった. 神戸ポートアイ ランドホールは, 神戸市が「明日を開く先端的国際都市」をめ ざし，世界最初の「住み，働き，悡い，学び，集う」といら近 代的, 総合的機能を備えた海上文化都市として作られたポート アイランドに建設された多目的ホールである.

ホール内ボックス席でホールの照明，施設について説明を受 けたのち，アリーナの照明，電光掲示，音響調整室などの見学 をした（施設の詳細については, 照明学会誌, 施設報告や照明 のデータ・シートなどを参照下さい).

神戸ポートアイランドホールは, 本年 8 月に世界 100 か国に のぼる若人が集い, 競ったユニバシアード神戸大会の体操とバ レーボールの会場になったところで，体操の華麗な演技と， ハ レーボール優勝の感動的なシーンを思い浮かべながらホールを 後にし，黄金色の稲穂波打つ播州路を一路次の見学先，山崎実 験センターへ向かった.

山崎実験センターは, 種々の環境下に打ける機器の寿命判定 や工事方法を, 実規模設備で長期実証テストとして研究するた めに, 関西電力株式会社総合技術研究所の付属実験所として, 兵庫県宾栗郡山崎町の山間に, 自然の地形を利用して設置され たものである。

実験研究施設は, 広さ約 10 万 $\mathrm{m}^{2}$ (甲子園球場の約 2 倍半) の構内に, 50 万 $\mathrm{V}$ 級大束径架空電線路（鉄塔 4 基，線路長 800 m) をもつ架空送電研究施設，地中送電ケーブル用洞道 (160 m）をもつ地中送電研究施設，模擬配電線路約 $3 \mathrm{~km}$ をるつ配 電研究施設, $50 \mathrm{~kW}$ 集光単結晶シリコンアレーをもつ太陽光発 電研究施設などがある。

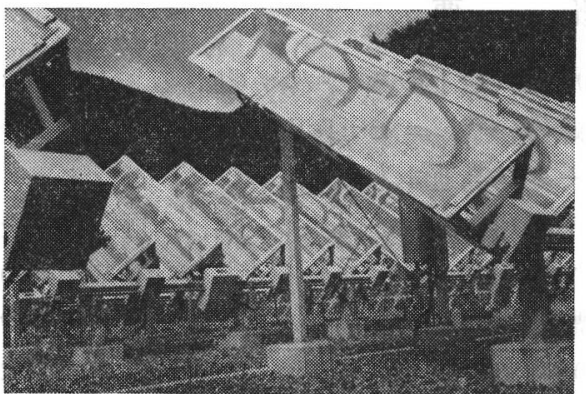

図 1 太陽光発電システム

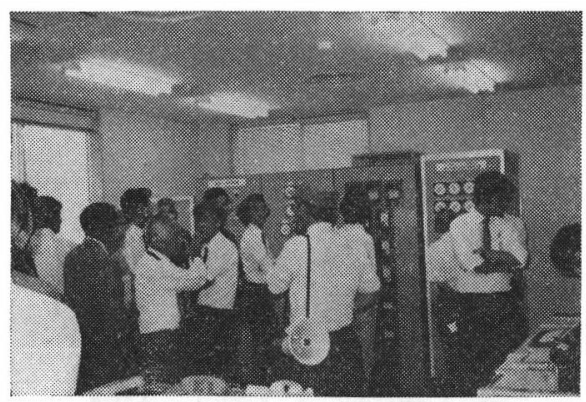

図 2 同上用DC/AC 変換システム

構内をバスで移動しながら，太陽電池アレーと追尾機構, $\mathrm{DC} / \mathrm{AC}$ 変換システム, 送電線加振装置, 各種環境実験システ ムなどの説明を受けた・実験はすべてコンピュータを利用した 自動 Data Information Acquisition System で行なわれてい る. また太陽光発電システムは, 外部配電系統に連繫されてい るとのことである. 睛天の日にはここで発電された太陽ェネル ギーは, どこかの家庭で電化製品を動かしていることでしょう。

山崎実験センターへ行く途中には, その昔平家の武士が 住 み，その子孫が住むといわれる母栖の集落があり，秋は紅葉と のコントラストも美しい落差 $40 \mathrm{~m}$ の「母栖の滝」がある景勝 の地も近いとのことである.

本日は，新しい照明技術を駆使したホール照明とより安定し た電力を供給するための最新の技術を開発，実用化するための スケールの大きな実験施設を見学することができ，楽しく，有 意義な一日に参加者一同満足しながら帰途についた。

最後に，施設の説明，案内をいただいたかたがたに心から感 謝いたします。
（専門会員 浦山 隆） 